\title{
Daily sperm production and epididymal sperm reserves of pubertal and adult rats
}

\author{
G. W. Robb, R. P. Amann and G. J. Killian \\ Dairy Breeding Research Center, The Pennsylvania State University, University Park, \\ Pennsylvania 16802, U.S.A.
}

\begin{abstract}
Summary. Rats were considered to be pubertal at 50 days of age when spermatozoa were first found in the tail of the epididymis. Sperm production/g testis increased up to 75 days of age and testicular weight increased until 100 days of age. Sperm reserves in the tail of the epididymis were not maximal until 100 days of age. Therefore, Wistar rats are not sexually mature until 100 days. Sexually mature rats had testes weighing $3.7 \mathrm{~g}$, produced $86 \times 10^{6}$ spermatozoa or $24 \times 10^{6}$ spermatozoa/g testicular parenchyma daily, and their paired epididymides contained $295 \times 10^{6}$ spermatozoa in the head + body and $440 \times 10^{6}$ spermatozoa in the tail.
\end{abstract}

\section{Introduction}

The laboratory rat is frequently used for research in reproductive physiology. For many years it has been recognized that testicular growth continues in rats until 100-125 days of age. Nevertheless, rats less than 100 days of age are sometimes used as adults to study reproductive processes. This practice may be inadvisable because in other species the maximum reproductive capacity of a male, in terms of sperm production or epididymal sperm reserves, is not attained until the testes reach adult size (Amann \& Almquist, 1976). Sexual maturity, the age when a male first attains maximum daily sperm production, is not synonymous with puberty and occurs some time after puberty (Amann, 1970). To establish when rats become sexually mature, we evaluated their daily sperm production and epididymal sperm reserves.

\section{Materials and Methods}

Litters of Wistar rats born in late June were standardized to 10 young on the day after birth. At 21 days of age, the rats were weaned and the males were housed individually at $22^{\circ} \mathrm{C}$ in a $12 \mathrm{~h}$ light: $12 \mathrm{~h}$ dark photoperiod. Laboratory rat chow and water were always available. Rats were randomly assigned to treatment groups. Testes and epididymides were collected at 20,30,40,50,75, 100 and 125 days of age $(\mathrm{N}=20,20,28,28,28,32$ and 32 rats, respectively). Data for 16 rats born in midNovember, similarly reared and killed at 45 days of age, were also included. Rats born in June received a single subcutaneous injection of $0.2 \mu \mathrm{g}$ chlorpromazine $-\mathrm{HCl} / \mathrm{g}$ body weight or the vehicle alone on Days 8,10 or 12 after birth. Rats born in November received $20 \mu \mathrm{g}$ chlorpromazine$\mathrm{HCl} / \mathrm{g}$ body weight or the vehicle at 10 days of age. Rats were treated with chlorpromazine- $\mathrm{HCl}$ in two experiments because Ladosky, Kesikowski \& Gaziri (1970) have reported that a single injection of chlorpromazine- $\mathrm{HCl}(20 \mu \mathrm{g} / \mathrm{g})$ accelerated the onset of spermatogenesis. However, analyses of variance revealed that treatment with chlcrpromazine- $\mathrm{HCl}$ did not alter any of the variables studied in the present experiments and, therefore, the data were pooled across both experiments and all drug treatments for analyses.

Each rat and its testes, head + body of the epididymis and tail of the epididymis were weighed. From the rats aged 40-125 days, the tunica albuginea was removed from one testis and the parenchyma was homogenized in $50 \mathrm{ml}$ saline-Triton-Merthiolate (STM; 0.15 M-NaCl, 0.05\% (v/v) Triton X-100, and Merthiolate (E. Lilly \& Co., Indianapolis) to give $0.25 \mathrm{M}$-thimerosal) in a 
semimicro Waring Blender for 2 min (Amann \& Lambiase, 1969). Elongated spermatid nuclei with a shape characteristic of step 17-19 spermatids (Clermont, Leblond \& Messier, 1959) and resistant to homogenization were counted. Counts for 6 haemocytometer chambers were averaged. The numbers of spermatid nuclei per testis and per gram of testis were calculated and these values were divided by 6.10 days (Amann, Johnson, Thompson \& Pickett, 1976) to convert them to daily sperm production. This time divisor was obtained from published data (Clermont et al., 1959) that stages IV-VIII, containing step $17-19$ spermatids, in the rat represent $48.0 \%$ of one cycle of the seminiferous epithelium which has a duration of 12.75 days (Hilscher \& Hilscher, 1969). For 7-9 rats per age group, one epididymis was stored at $-20^{\circ} \mathrm{C}$ for subsequent determination of sperm reserves. After thawing, the head + body or tail of the epididymis was minced and homogenized in $50 \mathrm{ml}$ STM fluid for $2 \mathrm{~min}$ (Amann \& Lambiase, 1969). The number of spermatozoa in each homogenate was determined as above and the total numbers of spermatozoa in the parts of the epididymis were calculated. The mean time for sperm transit through the epididymis also was calculated by dividing the number of spermatozoa in each portion of the epididymis by the daily sperm production of the associated testis (Amann et al., 1976).

Data for body and organ weights and for daily sperm production were evaluated by analyses of variance after $\log _{10}$ transformation to correct for the heterogeneity of variance observed with time. Transformation of data for sperm reserves and epididymal transit time was unnecessary. If the F-ratio was significant $(P<0.05)$, differences among means were evaluated with Duncan's multiple range test (Kramer, 1956). The mean and 95\% confidence interval are given in Table 1 because a single s.e.m. cannot be calculated from transformed data.

\section{Results and Discusssion}

At each age, the body weight of rats (Table 1) exceeded values published by commercial suppliers of rats, perhaps as a consequence of standardizing litter size to 10 young. This procedure also may have reduced the variance in testicular size, sperm production and epididymal sperm reserves of rats at a given age in comparison to values which might have been attained if the rats had been allowed to remain as litters of 7-18 young until weaning. Mills, Mills \& Means (1977) found that testicular weight had a lower variance when young rats were purchased on the basis of body weight rather than age.

Testicular weight increased rapidly up to 75 days of age (Table 1) and growth continued until 100 days of age. For 125-day-old rats, the correlation between body weight and paired testes weight was insignificant $(r=0.24 ; P>0.05 ; \mathrm{N}=31$ ). The growth curve for the head + body of the epididymis from 40 to 125 days of age was similar to that for the testis between 20 and 100 days of age, but at 75 days of age the epididymal tail weighed only $65 \%$ of the weight at 125 days compared with a value of $83 \%$ for the head + body. The increase in the weight of the tail of the epididymis between 100 and 125 days of age was significant $(P<0.05)$. Vesicular gland weight increased throughout the study. Thus, growth of the testis ceased before that of the tail of the epididymis and certain accessory sex glands.

Between 40 and 45 days of age the efficiency of sperm production increased rapidly (Table 1 ). Sperm production/g testis reached the adult level of $24 \times 10^{6}$ spermatozoa/day by 75 days of age and daily sperm production/rat also stabilized at this age. In 100- and 125-day-old rats, the sperm production was consistent $\left(23.9 \pm 0.24 \times 10^{6}\right.$ spermatozoa/g testis; s.e.m.) and was independent of testis weight $(r=0 \cdot 18 ; \mathrm{N}=62)$.

At 45 days of age, only a few spermatozoa were found in the epididymis. Before 75 days of age, the head + body contained more spermatozoa than did the tail of the epididymis (Table 1). Epididymal sperm reserves did not increase significantly after Day 100. At 125 days of age, the paired tails contained $60 \pm 1 \%$ of the total epididymal reserves of $735 \times 10^{6}$ spermatozoa. The epididymal sperm reserves of the 125-day-old rats (Table 1) are similar to those reported for Wistar rats purchased as retired breeders (Amann et al., 1976). 


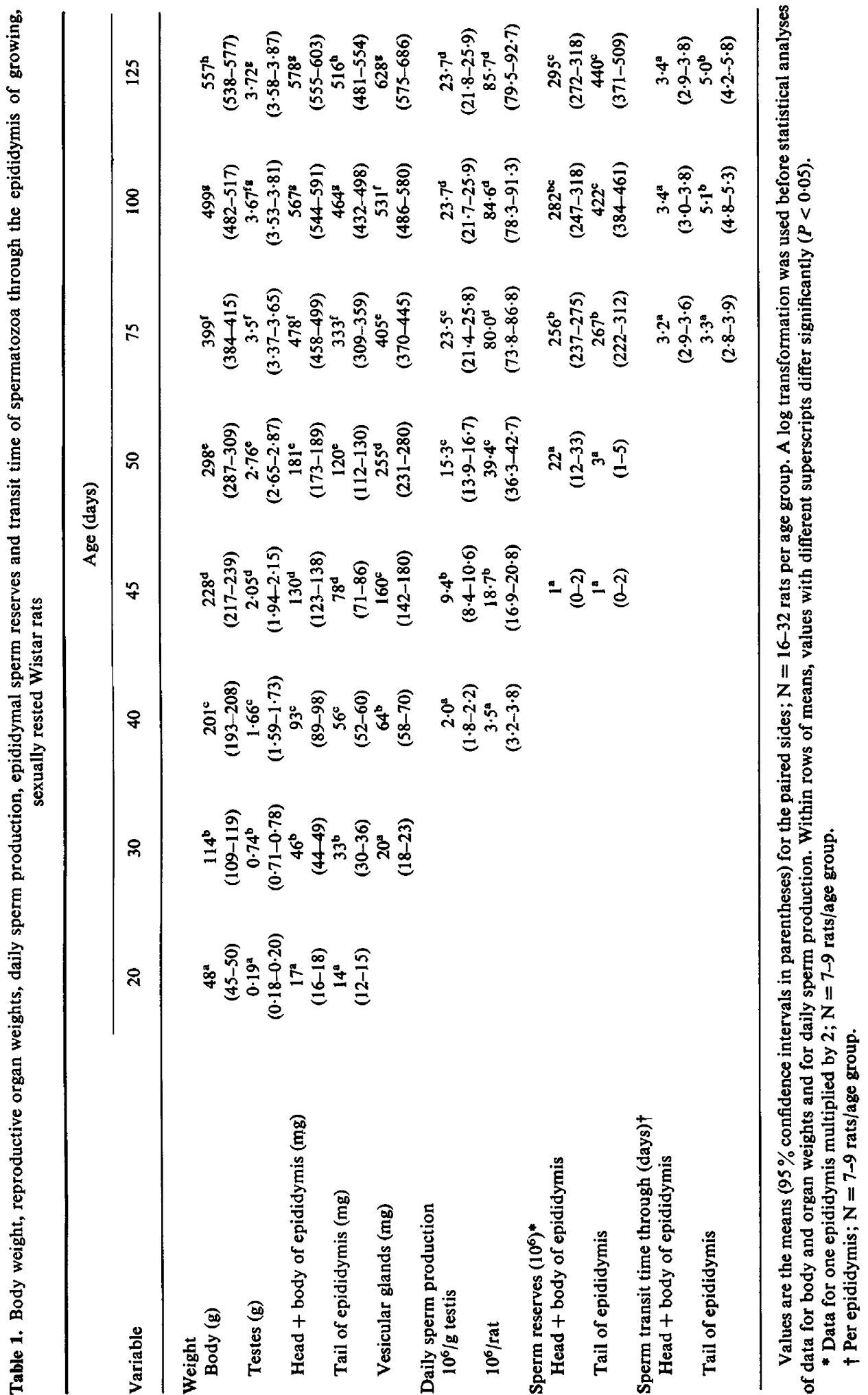


For 100- and 125-day-old rats (data were available for a total of 16 rats), the correlations between daily sperm production and sperm reserves in head + body or in the tail of the epididymis were low ( $r=0.19$ and 0.42 , respectively). The independence of daily sperm production and sperm reserves in rats is consistent with data for other species (Amann, 1970). The correlation between the sperm reserves in the head + body and in the tail of the epididymis was $0.47(P<0.05)$.

The epididymal sperm reserves in our sexually inactive rats (Table 1) were much greater than the values reported by Saksena, Dahlgren, Lau \& Chang (1977) who recovered $89 \times 10^{6}$ and $271 \times 10^{6}$ spermatozoa (after multiplication $\times 2$ ) from the head + proximal body of the epididymis and from the distal body + tail of the epididymis + vas deferens, respectively. The total of $360 \times 10^{6}$ spermatozoa is about half the value of $735 \times 10^{6}$ spermatozoa which we found, although our figures do not include cells in the extra-epididymal vas deferens. This discrepancy may result from strain differences (albino rats were used in both studies), but is probably a consequence of the procedures used to liberate spermatozoa from the epididymal tissue and the fact that the rats used by Saksena et al. (1977) apparently mated on the day before death. Mating should not reduce the number of spermatozoa in the head + body of the epididymis (Amann \& Almquist, 1976; Lambiase \& Amann, 1969) and, therefore, we believe that the maceration technique of Hunt, Lubicz-Nawrocki \& Chang (1976) which was used by Saksena et al. (1977) is probably less efficient for liberating spermatozoa than the homogenization technique (Amann \& Lambiase, 1969) which we used.

At 75 days of age, the time required for spermatozoa to pass through the head + body of the epididymis was similar $(P>0.05)$ to that in 125-day-old rats, but the transit time in the tail of the epididymis was $35 \%$ less $(P<0.05)$ than in 100 - or 125 -day-old rats (Table 1$)$. Similarly, in young bulls sperm transit through the tail of the epididymis is more rapid than in adult bulls although values for the head and body of the epididymis are similar (Amann \& Almquist, 1976).

If puberty is defined as the age when a male is first capable of reproduction, the data in Table 1 indicate that rats $<50$ days old are unlikely to be pubertal. Male rats are normally fertile and paired with females when the males are 70-80 days old (Short \& Woodnott, 1969). Although this is 20-30 days after the postulated attainment of puberty, our data show that such rats arenot sexually mature. If sexually mature males are required for physiological studies, rats aged at least 100 days should be used.

This research was supported by grant HD-07244 and funds from the Pennsylvania Agriculture Experiment Station and was authorized for publication as Paper No. 5412 in the Journal Series. Mrs J. Eastman and Mrs K. Robb provided skilled technical assistance.

\section{References}

Amann, R.P. (1970) Sperm production rates. In The Testis, Vol. 1, pp. 433-482. Eds A. D. Johnson, W. R. Gomes \& N. L. VanDemark. Academic Press, New York.

AmANN, R.P. \& AlmQUist, J.O. (1976) Bull management to maximize sperm output. Proc. 6th Tech. Conf. Anim. Reprod. pp. 1-10. National Association of Animal Breeders. Columbia, Missouri.

Amann, R.P. \& Lambiase, J.T., JR (1969) The male rabbit. III. Determination of daily sperm production by means of testicular homogenates. $J$. Anim. Sci. 28, 369-374.

Amann, R.P., Johnson, L., Thompson, D.L., JR \& PickeTt, B.W. (1976) Daily spermatozoal production, epididymal spermatozoal reserves and transit time of spermatozoa through the epididymis of the rhesus monkey. Biol. Reprod. 15, 586-592.

Clermont, Y., Leblond, C.P. \& Messier, B. (1959) Durée du cycle de l'épithélium séminal du rat. Archs Anat. microsc. Morph. exp. 489, 37-55.
Hilscher, W. \& Hilscher, B. (1969) Autoradiographische Untersuchungen uber die Kinetik der Spermatogenese der Wistarratte unter besonderer Berücksichtinung der Spermatocytogenese. Z. Zellforsch. mikrosk. Anat. 96, 625-640.

Hunt, D.M., Lubicz-Nawrocki, C.M. \& Chang, M. C. (1976) The effects of 17ß-estradiol and medroxyprogesterone acetate alone and in combination with $\alpha$-chlorohydrin on reproductive function in the male rat. Biol. Reprod. 14, 544-548.

Kramer, C.Y. (1956) Extension of multiple range tests to group means with unequal numbers of replications. Biometrics 12, 307-310.

LADOSKY, W., KESIKOWSKI, W.M. \& GAZIRI, I.F. (1970) Effect of a single injection of chlorpromazine into infant male rats on subsequent gonadotrophin secretion. J. Endocr. 48, 151-156.

LAmbiase, J.T., JR \& AMANN, R.P. (1969) The male rabbit. V. Changes in sperm reserves and resorption 
rate induced by ejaculation and sexual rest. J. Anim. Sci. 28, 542-549.

Mills, N.C., Mills, T.M. \& Means, A.R. (1977) Morphological and biochemical changes which occur during postnatal development and maturation of the rat testis. Biol. Reprod. 17, 124-130.

Saksena, S.K., Dahlgren, L., Lau, I.F. \& Chang, M. C. (1977) Reproductive and endocrinological features of male rats after treatment with cadmium chloride. Biol. Reprod. 16, 609-613.

ShorT, D.J. \& WoodnotT, D.P. (1969) The I.A.T. Manual of Laboratory Animal Practice and Techniques, p. 356. C. H. Thomas, Springfield, lllinois.

Received 6 December 1977 